\title{
Evsel Katı Atık Yönetim Senaryolarının Yaşam Döngüsü Analizi: Melikgazi İlçesi (Kayseri) Örneği
}

\author{
Emine Irbaş ${ }^{1 \oplus}$, Filiz Dadaşer-Çelik ${ }^{1, \oplus}$ \\ ${ }^{1}$ Erciyes Üniversitesi, Mühendislik Fakültesi, Çevre Mühendisliği Bölümü, 38039, Kayseri. \\ Özet
}

Nüfus artışı ve teknolojik gelişmeler nedeniyle katı atık üretimi hızla artmaktadır. Katı atıklardan kaynaklanan olumsuz etkileri azaltmak için atık yönetiminde çevresel sürdürülebilirliği de dikkate alan entegre yönetim yaklaşımlarının geliştirilmesi büyük önem arz etmektedir. Yaşam döngüsü analizi bir ürün veya hizmetin çevresel etkilerinin değerlendirilmesi için kullanılabilecek araçlardan biridir. Bu çalışmada, Kayseri İli Melikgazi İlçesi nde evsel katı atık yönetimi için seçilmiş alternatif yaklaşımlar yaşam döngüsü analizi kullanılarak incelenmiştir. Katı atı yönetim alternatifleri olarak dört adet senaryo belirlenmiştir. Senaryo 1, atıkların toplanması, depo sahasına taşınması ve düzenli depolanmasını içermektedir. Senaryo 2'de geri dönüşebilir atıklar kısmen kaynakta ayrıştırılmakta ve kalan atıklar ise düzenli depo sahasına taşınarak, depolanmaktadır. Senaryo 3 'te geri dönüșebilir atıkların tamamı kaynakta ayrıştırılmakta ve diğer atıklar ise düzenli depo sahasına taşınmakta ve depolanmaktadır. Senaryo 4'te ise geri dönüşebilir atıkların tamamının kaynakta ayrıştırılması sonrası kalan atıkların \%50'si kompostlama ve \%50'si düzenli depolama ile bertaraf edilmektedir. Bu senaryolar yaşam döngüsü analizinde değerlendirilirken, hesaplama yöntemi olarak IWM (Integrated Waste Management-Entegre Atık Yönetimi) modeli kullanılmıştır. Çalışmada, tüm senaryolar için net enerji kullanımı / yenilenemeyen enerji kaynakları tüketme potansiyeli (GJ), küresel ısınma potansiyeli $\left(\mathrm{kg} \mathrm{CO}\right.$-eşdeğeri), asidifikasyon potansiyeli ( $\mathrm{kg} \mathrm{SO}_{2}$-eşdeğeri) ve ötrofikasyon potansiyeli ( $\mathrm{kg} \mathrm{O} \mathrm{O}_{2}$-eşdeğeri) hesaplanmıştır. Melikgazi Belediyesi için Senaryo 3 ve Senaryo 4 'ün hem enerji tüketimi hem de çevresel etkileri açısından diğer alternatiflere göre daha avantajlı olduğu tespit edilmiştir. Geri dönüșebilir atıkların kaynakta ayrıştırılması çevresel etkilerin azaltılmasında etkili olmuştur. Ayrıca kompostlama uygulaması düzenli depolamaya nispeten daha az çevresel etki oluşturmuştur.

Anahtar Sözcükler

Entegre Katı Atık Yönetimi, Yaşam Döngüsü Analizi, Kayseri

\section{Life Cycle Assessment for Solid Waste Management: A Case Study for Melikgazi Municipality (Kayseri)}

\begin{abstract}
Solid waste production increases rapidly due to population growth and technological developments. Reducing negative impacts from solid wastes requires the development of integrated management approaches that consider environmental sustainability. Life cycle assessment is one of the tools that can be used to assess environmental impacts of products and processes. In this study, the alternative management scenarios for solid wastes were examined using life cycle assessment approach for the Melikgazi Municipality, Kayseri. Four scenarios were identified. In Scenario 1, all wastes are collected, transferred to landfill site and landfilled. In Scenario 2 , recyclable wastes are partially separated at the source and the remaining wastes are transferred and landfilled. In Scenario 3, all recyclable wastes are separated at the source and other wastes are landfilled. In Scenario 4, after separation of recyclable wastes, other wastes are either composted (50\%) or landfilled (50\%). Life cycle assessment for all scenarios was based on IWM (Integrated Waste Management) model. Net energy use / non-renewable energy resources depletion potential (GJ), global warming potential (kg $\mathrm{CO}_{2}$-equivalent), acidification potential ( $\mathrm{kg} \mathrm{SO} \mathrm{S}_{2}$-equivalent) and eutrophication potential ( $\mathrm{kg} \mathrm{O}_{2}$-equivalent) were calculated for all scenarios. For Melikgazi Municipality, Scenario 3 and 4 provided more advantageous alternatives in terms of energy consumption and environmental impacts. Separating recyclable wastes at the source has been effective in reducing environmental impacts. In addition, composting application has created less environmental impact compared to landfilling.
\end{abstract}

$\underline{\text { Keywords }}$

Solid Waste Management, Life Cycle Assessment, Kayseri

\section{Giriş}

Katı atıklar "üreticisi veya fiilen elinde bulunduran gerçek veya tüzel kişi tarafından çevreye atılan veya bırakılan ya da atılması zorunlu olan herhangi bir madde veya materyal” olarak tanımlanmaktadır (URL-1 2015). 
Bütün dünyada nüfustaki artışla birlikte gerçekleşen sanayileşme, kentleşme ve ekonomik büyüme üretilen katı atık miktarlarının da artmasına neden olmaktadır (Khandelwal vd. 2019). Küresel olarak atık üretiminin 1965 'te 635 milyon ton'dan 2015 'te 1999 milyon ton'a yükseldiğini ve 2050'ye kadar 3539 milyon ton'a ulaşacağı modelleme teknikleri kullanılarak tahmin edilmektedir (Chen vd. 2020). Atıkların sera gazı emisyonlarını ve azot kirliliğini artırma dâhil pek çok olumsuz çevresel etkisi bulunmaktadır (Chen vd. 2020). Artan atık miktarı ve olumsuz çevresel etkileri gelecekte atık yönetimin daha önemli hale geleceğini göstermektedir.

Yaşam döngüsü analizi yaklaşımı farklı katı atık yönetim alternatiflerinin değerlendirilmesi için kullanılabilecek yöntemlerden biridir (Güereca vd. 2006). Bu yaklaşım kullanan ilk çalışmalar 1960’ların sonuna doğru ortaya çıkmış ve 1990’lı yıllardan beri karmaşık sistemlerde gittikçe daha çok tercih edilen ve sürekli geliştirilen, yenilenen bir yöntem haline gelmiştir (Guinee vd. 2011). Yaşam döngüsü analizi, Çevresel Toksikoloji ve Kimya Derneği (Society of Environmental Toxicology and Chemistry) (SETAC) tarafından "bir ürünün, işlemin veya faaliyetin çevresel yükünü, enerjiyi, kullanılan maddeleri ve çevreye verilen atıkların türlerini ve miktarlarını belirleyerek, çevresel gelişmeleri etkileyecek olanakları değerlendirip uygulayacak, objektif bir işlem” olarak tanımlanmaktadır (SETAC 1991). Yaşam döngüsü analizi, hammadde temini aşamasından başlayarak, çevresel etkileri de analizlere dâhil ederek, üretim (imalat), tüketim (kullanım), tekrar kullanım ve atık yönetimi sürecinde, bertaraf edilmesine kadar, kullanıcılar tarafından değerlendirilmesini sağlayan faydalı bir yöntemdir (Özeler vd. 2006).

Yaşam döngüsü analizi katı atık yönetiminde uygulama için ideal bir yöntem sunar. Katı atıkların yönetiminde coğrafi konum, atıkların özellikleri, enerji kaynakları, bazı bertaraf seçeneklerinin varlığı ve atık yönetiminde elde edilen ürünler için pazar büyüklüğü bölgeden bölgeye çok farklıdır (Mendes vd. 2004). Bu açıdan teknik, ekonomik ve sosyal açıdan göz önünde bulundurulması gereken karmaşık ve çok disiplinli bir sorundur. Şekil 1 katı atıklar yönetiminin yaşam döngüsünü bütünsel bir şekilde göstermektedir. Evsel katı atık yönetimi en az üç aşamadan oluşur; toplama, taşıma ve arıtma. Süreç boyunca, çok sayıda etki vardır. Örneğin, atıkların toplanması, farklı tipteki torba ve konteynerlerin üretimi, kullanımı, nakil araçlarının kullanımı ve transfer istasyonlarının yapımı, bakımı ve yıkımı nedeniyle çeşitli türlerde çevresel sonuçlara sahiptir (Rives vd. 2010; Chen 2012).

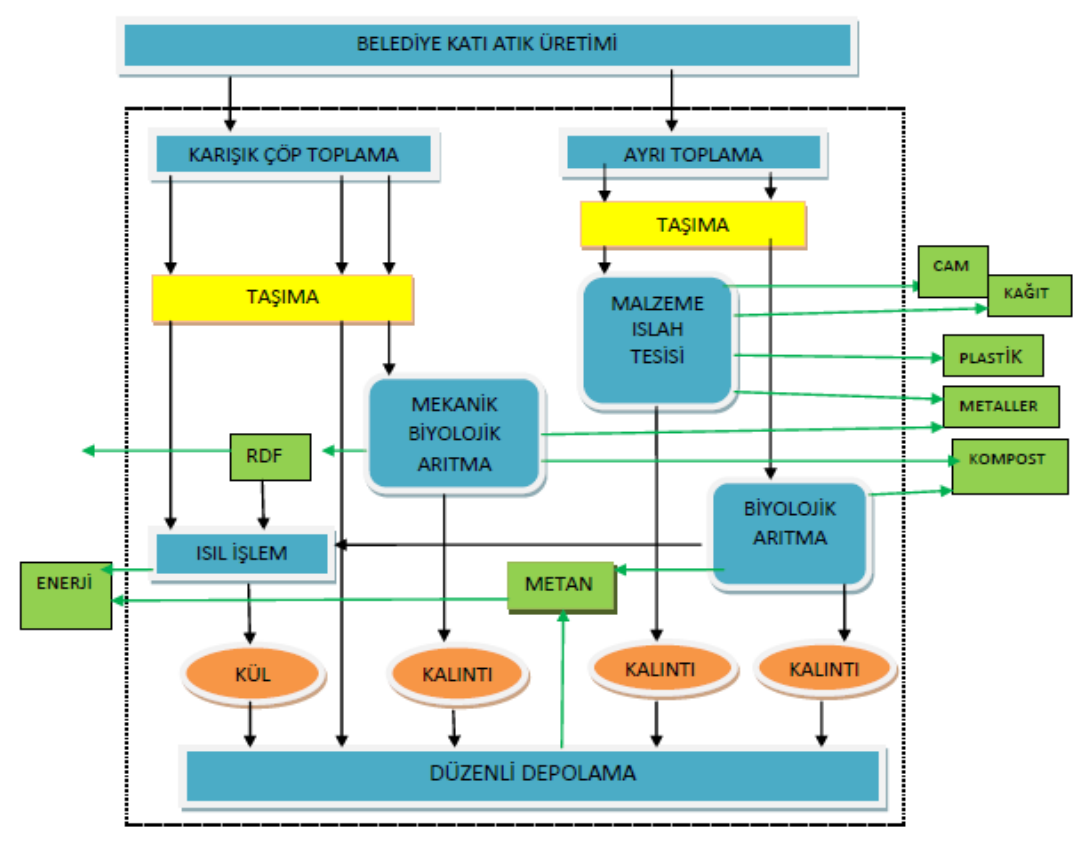

Şekil 1: Katı atık yönetim sisteminin yaşam döngüsü (Konstadinos 2011)

Katı atık yönetiminde yaşam döngüsü analizinin kullanımı ile ilgili, uluslararası alanda ve Türkiye'de yapılan bazı çalışmalar incelenmiştir. White vd. (1995) entegre katı atık yönetim modelini (IWM1) geliştirmiştir. Clift vd. (2000) entegre katı atık yönetimi için yaşam döngüsü analizi metodolojisini açıklamıştır. Ekvall ve Finnveden (2000) kağıt atıkları örneğinde yaşam döngüsü analizinin uygulamasını yapmıştır. Weitz vd. (2002) belediye katı atık yönetiminin Amerika Birleşik Devletleri (ABD)'ndeki sera gazı emisyonlarına etkisini değerlendirmiştir. Finnveden vd. (2005) katı atıklar için enerji dengesini yaşam döngüsünde değerlendirmiştir. Kaplan vd. (2009) Delawere için katı atık yönetimi planlamasının yaşam döngüsü analizi ile desteklemesini incelenmiştir. Hong (2010), Çin'de dört belediyenin katı atık yönetim senaryolarını yaşam döngüsü analiz ile incelemişsir. Othman vd. (2013) bazı Asya ülkelerinde entegre katı atık yönetiminde yaşam döngüsü değerlendirmesi araştırılmıştır. Evsel katı atık yönetim sistemlerinin yaşam döngüsü analiziyle değerlendirilmesi Naghibzadeh vd. (2015), Mboowa vd. (2017), Maalouf ve El-Fadel (2019) gibi pek çok diğer çalışmada da incelenmiştir. Türkiye'de yapılan çalışmalar da son yıllarda artış göstermiştir. 
Özeler (2001) ve Özeler vd. (2006) yaşam boyu değerlendirme yönetiminin evsel katı atık yönetiminde Ankara örneğini incelemişlerdir. Çokaygil (2005) atık yönetim planlamasında yaşam döngüsü analizini araştırmış ve Özkan (2008) kentsel katı atık yönetimi sistemlerinin oluşturulmasında farlı karar verme tekniklerinin kullanımı araştırmıştır. Banar vd. (2009) Eskişehir ili için katı atık yönetimi sisteminin yaşam döngüsü değerlendirmesini geliştirmiştir. Çil (2013), Yalova kentsel katı atık yönetim alternatiflerini çevresel yaşam döngüsü analizi çerçevesinde incelemiştir. Erses Yay (2017) SakaryaSerdivan ilçesi ambalaj atıkları yönetiminin çevresel etkileri yaşam döngüsü analizi ile değerlendirmesi konusunda çalışmalar yapmıştır. Çetinkaya vd. (2018) Aksaray ili için ve Özer ve Yay (2021) Kırklareli ili için katı atık yönetim alternatiflerini aynı yöntemle karşılaştırmıştır.

$\mathrm{Bu}$ çalışmada, Kayseri ili Melikgazi ilçesi evsel katı atık yönetim sisteminin yaşam döngüsü analizi ile değerlendirilmesi ve katı atık yönetimi için farklı alternatiflerin karşılaştırılması konu edilmektedir. Bu amaçla, dört farklı evsel katı atık yönetimi senaryosu oluşturulmuş ve bu senaryolar net enerji kullanımı/yenilenemeyen enerji kaynakları tükenme potansiyeli (GJ), küresel isınma potansiyeli ( $\mathrm{kg} \mathrm{CO}_{2}$-eşdeğeri, asidifikasyon potansiyeli $\left(\mathrm{kg} \mathrm{SO}_{2}\right.$-eşdeğeri) ve ötrofikasyon potansiyeli ( $\mathrm{kg} \mathrm{O}_{2}$-eşdeğeri) açısından karşılaştırılmıştır.

\section{Materyal ve Yöntem}

Bu çalışmada, Kayseri ili Melikgazi ilçesi için farklı katı atık yönetim alternatifleri yaşam döngüsü analizi ile karşılaştırılmaktadır. Melikgazi ilçesi Kayseri'nin merkez ilçelerinden biridir (Şekil 2). $600 \mathrm{~km}^{2}$ alana sahip olan ilçenin, Türkiye İstatistik Kurumu verilerine göre 2020 yılında nüfusu yaklaşık 583 bin kişidir. İlçeye bağlı 1 belediye ve 81 mahalle bulunmaktadır. Melikgazi ilçesi büyük oranda yerleşim alanları, ticari alanlar ve organize sanayi bölgelerini içermektedir.

Çalışmada yaşam döngüsü analizi, IWM (Integrated Waste Management - Entegre Atık Yönetimi) modeli (White vd. 1995) kullanılarak yürütülmüştür. Aşağıda öncelikle IWM modeli hakkında genel bilgiler sunulmaktadır. Daha sonra çalışmada kullanılan Melikgazi ilçesi’ne ait veriler ayrıntılı olarak açıklanmaktadır.

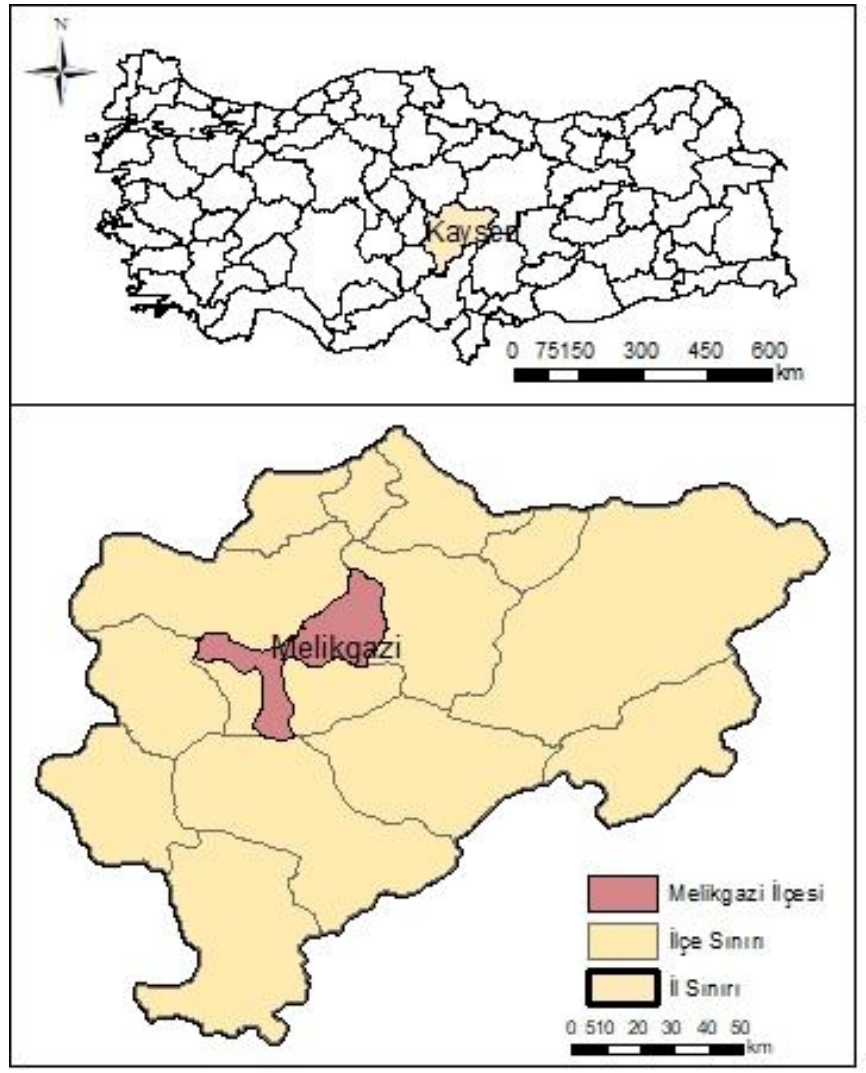

Şekil 2: Kayseri ve Melikgazi ilçesi'nin konumu

\subsection{Entegre Atık Yönetimi (IWM) Modelinin Genel Yapısı}

IWM modeli, hem çevresel hem de ekonomik yaşam döngüsü envanterlerini içeren Microsoft Excel programında çalışan bir bilgisayar modelidir. Model, White vd. (1995) tarafından geliştirilmiştir ve farklı katı atık yönetimi seçeneklerinin genel çevresel etkilerinin tahmin edilmesine izin vermektedir (Özeler vd. 2006; Özeler 2001). 
Yaşam döngüsü boyunca katı atık akışı, modelde takip edilir. Katı atığın yaşam döngüsündeki aşamaların her biri, giriş soruları içeren bir kutu ile temsil edilir ve bunların cevapları, dikkate alınan katı atık yönetim sistemini tanımlar. Model yapısındaki kutular, ön sınıflandırma ve toplama, ayırma, malzeme geri dönüşümü, biyolojik arıtma, yakma ve düzenli depolamadır. Her aşamada, materyaller geri kazanıldıkça, atık akımından çıkarılır ve geri kazanılmış bir materyal akışına girilir. Süreçlerden gelen diğer çıktılar, biriktikleri emisyon ve enerji için ilgili sütunlara girilir. Yaşam döngüsünün sonunda, tüm materyaller atık akışı sütunlarını terk etmiş veya ürünlere ya da emisyon sütunlarına girmiş olacaklardır. Model daha sonra seçilen bölgenin atık yaşam döngüsü envanterini üretmek için enerji tüketimini, enerji üretimini, geri kazanılan malzemeleri, kompost miktarlarını, havaya emisyonları, suya emisyonları ve nihai katı atıkları düzenler (White vd. 1995).

\subsection{Fonksiyonel Birim ve Sistem Sınırları}

Senaryolarda kullanılan fonksiyonel birim Kayseri ili Melikgazi ilçesi sınırlarında üretilen evsel katı atıkların miktarı olup, ton/yıl olarak tanımlanmıştır. Katı atıkların yaşam döngüsü analizi için seçilen sistem sınırları, ürünün değerini kaybettiği andan başlayarak atık halini alması ve kararlı depolama sahası halini alana kadar ya da hava veya su emisyonlarına dönüşmesine kadar veya tekrar bir değer edinene kadar olarak belirlenmiştir.

\subsection{Senaryoların Belirlenmesi}

Bu çalışmada Kayseri İli Melikgazi ilçesi evsel katı atığının yaşam döngüsü analizi/değerlendirmesi yapılmıştır. Mevcut evsel katı atık yönetimi ile geliştirilen farklı katı atık yönetim senaryoları oluşturulmuştur. Bu senaryolar Tablo 1'de açıklanmaktadır. Seçilen senaryolar Kayseri için kullanılan katı atık bertaraf yöntemleridir. Senaryo 1 'de 2016 yılına kadar kullanılan mevcut durum olan verilmiştir. Bu sisteme göre atıklar evlerden toplanmış, taşınmış ve düzenli olarak depolanmıştır. Senaryo 1 altında a ve b olarak belirtilen iki alt senaryo düzenli depolama sahasında sırasıyla gaz ve enerji kontrolünün mevcut olmadığı ve olduğu durumları yansıtmaktadır. Senaryo 2'de ise Melikgazi ilçesi'nde halen kullanılan katı atık bertaraf sistemi verilmiştir. Bu sisteme göre geri dönüşebilir atıklar kısmen kaynakta ayrıştırıldıktan sonra kalan atıklar toplanmakta, düzenli depo sahasına taşınmakta ve orada depolanmaktadır. Senaryo 3 'te geri dönüşebilir atıkların tamamı kaynakta ayrıştırılmakta, sonrasında toplama, taşıma ve düzenli depolama gerçekleştirilmektedir. Senaryo 4'te ise geri dönüşebilir atıkların kaynakta ayrıştırılması, kalan atıkların taşınması ve kompostlaştırma (\%50) ve düzenli depolama (\%50) sistemleri ile nihai bertarafının gerçekleştirilmesi söz konusudur.

Tablo 1: Melikgazi ilçesi için geliştirilen evsel katı atık yönetim alternatifleri

\begin{tabular}{lllllll}
\hline & $\begin{array}{c}\text { Kaynağında } \\
\text { Ayrıştırma }\end{array}$ & Toplama & Transfer & Düzenli Depolama & $\begin{array}{c}\text { Gaz ve } \\
\text { Enerji } \\
\text { Kontrolü }\end{array}$ & Kompostlaştırma \\
\hline Senaryo 1-a & Yok & Var & Var & Var & Yok & Yok \\
Senaryo 1-b & Yok & Var & Var & Var & Var & Yok \\
Senaryo 2 & Kismen Var & Var & Var & Var & Var & Yok \\
Senaryo 3 & Var & Var & Var & Var & Var & Yok \\
Senaryo 4 & Var & Var & Var & Var $(\% 50)$ & Var & Var $(\% 50)$ \\
\hline
\end{tabular}

Melikgazi Belediyesi katı atık yönetimi için belirlenen senaryolar yaşam döngüsü analizi çerçevesi içerisinde değerlendirilmiş olup, her bir senaryo için IWM modeli çalıştırılmıştır. Senaryolar, çevresel performanslarına göre karşılaştırılmıştır. Bu çevresel etkiler, enerji tüketimi/yenilenemeyen enerji tüketme potansiyeli, küresel 1sınma potansiyeli, asidifikasyon potansiyeli ve ötrofikasyon potansiyeli şeklindedir.

\subsection{Kullanılan Veriler}

$\mathrm{Bu}$ çalışmada Melikgazi Belediyesi’nden temin edilen 2017 yılına ait atık istatistikleri kullanılmıştır. 2017 yılında Melikgazi ilçesi nüfusu yaklaşık 563 bin kişidir. 2020 yılına kadar nüfus sadece \%3 değişim göstermiştir ve atık yönetim sisteminde bir değişiklik olmamıştır. Bu nedenle, 2017 yılı koşullarının halen geçerli olduğu söylenebilir.

Melikgazi Belediyesi'nden elde edilen verilere göre, ilçe kapsamında evsel katı atıklar 41 adet evsel katı atık toplama aracıyla (sıkıştırmalı) günlük 470 ton, aylık 14100 ton, yıllık yaklaşık 165000 ton olarak toplanmakta, Altınoluk ve İldem bölgelerinde bulunan aktarma istasyonuna getirilmektedir. Toplanan katı atıklar, aktarma istasyonlarından düzenli depo sahasına sevk edilmektedir İlçede kaynakta ayrıştırılan geri dönüşebilir atıkların toplanması için 15 adet araç kullanılmaktadır. Kaynakta ayrıştırma faaliyeti, 51 mahallede yapılarak, günlük 18 ton, aylık 534 ton, yıllık 6192 ton atık geri dönüşüm malzemesi olarak toplanmaktadır. Kaynakta ayrıştırma işlemi, belediyeye bağlı bulunan köylerde uygulanmamaktadır. Buna karşılık nüfusun yaklaşık olarak \%80’ine tekabül edilen kısımda ayrıştırma devam etmektedir. Tablo 2'de farklı senaryolarda atıklara uygulanan işlemlerle ilgili kabuller verilmektedir. 
Tablo 2: Katı atık yönetim senaryolarında atık miktarları ve uygulanan bertaraf yöntemleri

\begin{tabular}{cccccc}
\hline Atık Miktarı & Senaryo 1-a & Senaryo 1-b & Senaryo 2 & Senaryo 3 & Senaryo 4 \\
\hline $\begin{array}{c}\text { Toplam Atık Miktarı (ton/yıl) } \\
\text { Ayrı Toplanan Geri Dönüşebilir }\end{array}$ & 165000 & 165000 & 165000 & 165000 & 165000 \\
$\begin{array}{c}\text { Atık Miktarı (ton/yıl) } \\
\text { Kompostlama Uygulanan Atık } \\
\begin{array}{c}\text { Miktarı (ton/yıl) } \\
\text { Düzenli Depolamaya Giden } \\
\text { Atık Miktarı (ton/y1) }\end{array}\end{array}$ & 0 & 0 & 6192 & 35096 & 35096 \\
\hline
\end{tabular}

Türkiye genelinde, yapılan atık karakterizasyon çalışmalarında, atık oranları tüketim alışkanlıklarındaki değişiklikler, gelir düzeyindeki değişiklikler, göç, sosyoekonomik yapı vb. etkenlerden dolayı değişiklik göstermektedir. Kayseri ili için yapılan daha önceki çalışmalarda detaylı, güvenilir bir katı atık karakterizasyon çalışmasına rastlanmamıştır. Bu nedenle literatür taraması yapılmış ve sosyoekolojik yapısı açısından Kayseri’ye en yakın şehir olarak Bursa ili için yapılan karakterizasyon çalışması sonucu (Balahorli vd. 2015) kullanılmıştır. Bu çalışmada elde edilen değerler ve Melikgazi ilçesi için tahmin edilen değerler Tablo 3’te sunulmaktadır.

Tablo 3: Çalışmada kullanılan katı atık karakterizasyonu ve yıllık atık üretim değerleri

\begin{tabular}{ccc}
\hline Katı Atık Türü & $\begin{array}{c}\text { Geri Dönüşebilir Atık Oranları (\%) } \\
\text { (Balahorli vd. 2015) }\end{array}$ & Melikgazi İlçesi Atık Oranları (ton/yıl) \\
\hline Kağıt -karton & 6.19 & 10213 \\
Cam & 2.90 & 4785 \\
Pet & 0.52 & 858 \\
Poşet & 8.72 & 14388 \\
Plastikler & 2.15 & 3548 \\
Metaller & 0.78 & 1304 \\
Organik Madde & 52.15 & 86047 \\
Diğer Atıklar & 26.59 & 43857 \\
\hline
\end{tabular}

Toplama ve transfer aşamalarının etkilerini değerlendirmek için araçlarca kat edilen mesafe bilgisine ihtiyaç duyulmaktadır. Melikgazi Belediyesi’nden çöp araçlarının bir yılda kat ettikleri mesafe ile ilgili ölçüm değerleri alınmıştır. Çöp araçları yaklaşık 1430000 km/yıl mesafe almıştır. Buna karşılık, geri dönüşüm araçlarının seyahat bilgilerine ulaşılamamıştır. Aynı bölgeleri haftada bir defa ziyaret ettikleri varsayımına göre atıkların geri dönüşebilir kısmı için varsayım yapılmıştır. Buna göre Senaryo 2'de 180000 km/yıl, Senaryo 3 ve 4'de ise 304161 km/yıl yol aldıkları kabul edilmiştir. Çöp toplama araçlarının yakıt tüketim değerleri Melikgazi Belediyesi'nce toplanmış yakıt kullanım verileri kullanılarak hesaplanmıştır (1.96 km/litre). Geri dönüşebilir atık toplama araçları için ise $2.5 \mathrm{~km} / \mathrm{litre}$ şeklinde IWM modeli tarafından önerilen değer kullanılmıştır. Aktarma istasyonunda kullanılan dizel, elektrik enerjisi bilgileri IWM modelince önerilen değerlerdir. Aktarma istasyonu ve düzenli depo sahası arasındaki mesafe $20 \mathrm{~km}$ olarak kabul edilmiştir. Ayırma tesisi, kompostlama tesisi ve düzenli depolama tesisi ile ilgili Melikgazi Belediyesi’ne ait ölçülmüş veri bulunmamaktadır. Bu işlemler için IWM modelinin önerdiği değerler kullanılmıştır (Tablo 4).

Kayseri ilinde kullanılan elektrik enerjisinin kaynakları hakkında detaylı bir bilgiye ulaşılamamıştır. Çalışmada 2017 yılına ait atık verileri kullanıldığı için, TEIAŞ (2017) tarafından sunulan Türkiye için elektrik enerjisi üretim bilgileri ve kaynakları kullanılmıştır. Bu kaynağa elektrik enerjisinin \%33.6'sının kömür, \%32.5'inin doğalgaz ve \%30.2'inin yenilenebilir enerji/rüzgar ile elde edildiği kabul edilmiştir.

Çalışmada, tüm senaryolar için her bir katı atık yönetim aşamasının çevresel etkilerinin hesaplaması için aşağıdaki etki kategorileri incelenmiştir.

- Net enerji kullanımı / yenilenemeyen enerji kaynakları tüketme potansiyeli (GJ)

- Küresel ısınma potansiyeli ( $\mathrm{kg} \mathrm{CO}_{2}$-eşdeğeri )

- Asidifikasyon potansiyeli ( $\mathrm{kg} \mathrm{SO}_{2}$-eşdeğeri)

- Ötrofikasyon potansiyeli ( $\mathrm{kg} \mathrm{O}_{2}$-eşdeğeri) 
Tablo 4: Katı atık yönetim senaryolarında ayrıştırma, kompostlama ve düzenli depolama için kullanılan veriler ve yapılan varsayımlar

\begin{tabular}{|c|c|c|c|c|c|c|}
\hline Proses & Parametre & Senaryo 1-a & $\begin{array}{c}\text { Senaryo 1- } \\
\text { b }\end{array}$ & Senaryo 2 & Senaryo 3 & Senaryo 4 \\
\hline \multirow{2}{*}{$\begin{array}{l}\text { Ayırma } \\
\text { Tesisi }\end{array}$} & Enerji tüketimi (elektrik) (kwh/ton) & 25 & 25 & 25 & 25 & 25 \\
\hline & Enerji tüketimi(Doğal gaz) (m³/ton) & 0.264 & 0.264 & 0.264 & 0.264 & 0.264 \\
\hline Kompostlama & Enerji tüketimi (kwh/ton) & Yok & Yok & Yok & Yok & 21 \\
\hline \multirow{11}{*}{$\begin{array}{l}\text { Düzenli } \\
\text { Depolama }\end{array}$} & Karbon biriktirme & Yok & Yok & Yok & Yok & Yok \\
\hline & Gaz kurtarma & Yok & Var & Var & Var & Var \\
\hline & Gaz kurtarma verimi (\%) & 0 & 50 & 50 & 50 & 50 \\
\hline & Enerji kurtarma & Yok & Var & Var & Var & Var \\
\hline & Enerji kurtarma verimi (\%) & 0 & 30 & 30 & 30 & 30 \\
\hline & Yıllık yağış (mm) & 400 & 400 & 400 & 400 & 400 \\
\hline & Sizint1 suyu toplama sistemi & Var & Var & Var & Var & Var \\
\hline & Sizıntı suyu toplama verimi (\%) & 50 & 50 & 50 & 50 & 50 \\
\hline & Tüketilen enerji (Dizel) (litre/ton) & 0.22 & 0.22 & 0.22 & 0.22 & 0.22 \\
\hline & Tüketilen enerji (Doğal gaz) (m³/ton) & 0.028 & 0.028 & 0.028 & 0.028 & 0.028 \\
\hline & Tüketilen enerji (Elektrik) (kwh/ton) & 0.29 & 0.29 & 0.29 & 0.29 & 0.29 \\
\hline
\end{tabular}

\section{Bulgular}

\subsection{Enerji Tüketimi/ Yenilenemeyen Enerji Kaynakları Tüketme Potansiyeli}

Katı atık yönetim sistemlerinde enerji kullanımı özellikle atıkların toplanması ve taşınması esnasında söz konusudur. Buna karşılık düzenli depolama işleminde oluşan metan gazı enerji geri kazanımı için kullanılabilir. Bu çalışmada her bir senaryo için enerji tüketimi veya yenilenemeyen enerji kaynakları tüketme potansiyeli hem enerji tüketimlerini hem de enerji kazanımlarını dikkate alarak net enerji tüketimi şeklinde hesaplanmıştır. Yaşam döngüsü analizi net enerji tüketimi değerleri Şekil 3'te sunulmaktadır.

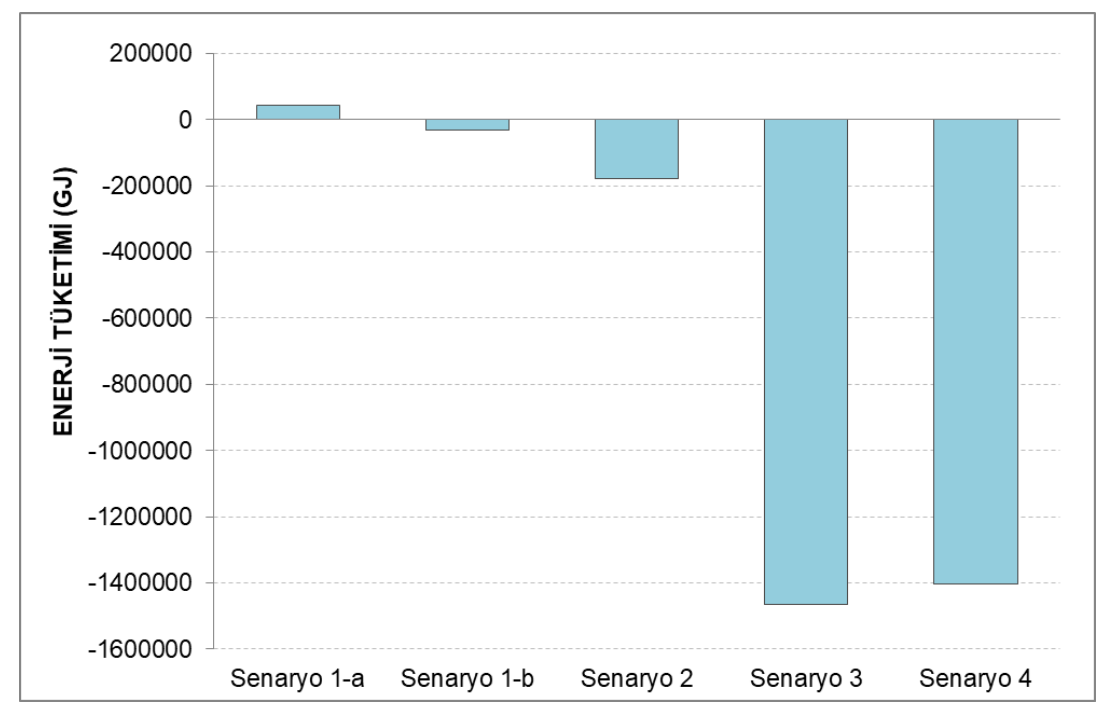

Şekil 3: Katı atık yönetim senaryolarının enerji tüketimi açısından karşılaştırılması

Senaryo 1-a'da enerji tüketimi pozitif bir değer, diğer senaryolarda ise negatif bir değerdir. Net enerji tüketimin negatif bir değer alması tüketilen enerjinin kazanılan enerjiden daha düşük olduğunu göstermektedir. Senaryo 1-a'da net enerji tüketimi 43893 GJ'dür. Bunun en önemli nedeni bu senaryoda enerji kazanımının (gaz ve enerji kontrolünün) mevcut olmamasıdır. Buna karşılık Senaryo 1-b, Senaryo 2, Senaryo 3 ve Senaryo 4'te gaz ve enerji kontrolü mevcut olduğu için enerji tüketimi değerleri negatif olarak gerçekleşmekte, diğer bir ifadeyle enerji kazancı oluşmaktadır. 
Senaryo 1-b, Senaryo 2, Senaryo 3 ve Senaryo 4 için net enerji tüketimleri sirasılla -31334 GJ, -179233 GJ, -1464026 ve -1403474 GJ olarak hesaplanmıştır. Enerji tüketimlerini işlenen atık bazında hesapladığımızda Senaryo 1-a'da 0.3 GJ/ton atık, Senaryo 1-b'de -0.2 GJ/ton atık, Senaryo 2'de -1.1 GJ/ton atık, Senaryo 3'de -8.9 GJ/ton atık ve Senaryo 4'de ise $8.5 \mathrm{GJ} /$ ton atık değerlerine ulaşılmaktadır.

Katı atık yönetimi senaryolarında farklı atık yönetim işlemlerinin etkileri Tablo 5 'te gösterilmektedir. Tablo 5'e göre taşıma ve toplama adımlarında enerji tüketimleri bütün senaryolarda hemen hemen aynıdır. Buna karşılık düzenli depolama esnasında gaz ve enerji kontrolünün mevcut olduğu senaryolarda önemli düzeyde enerji kazanımı gerçeklemektedir. Senaryo 5'te geri dönüştürülemeyen atıkların bir kısmı kompostlama ile bertaraf edildiği için kazanılan enerji miktarında azalma gerçekleşmiştir.

Tablo 5: Katı atık yönetim senaryolarında farklı işlemlerin enerji tüketimine etkisi (GJ)

\begin{tabular}{lccccc}
\hline Atık Yönetim İşlemi & Senaryo-1a & Senaryo 1b & Senaryo 2 & Senaryo 3 & Senaryo 4 \\
\hline Taşıma ve Transfer & 34882 & 34882 & 34942 & 35219 & 35277 \\
Ayrıştırma & 0 & 0 & 1981 & 11227 & 11227 \\
Geri Dönüşüm & 0 & 0 & 90372 & 337419 & 337419 \\
Düzenli Depolama & 9011 & -66216 & -61097 & -56670 & -11636 \\
Kompostlama & 0 & 0 & 0 & 0 & 15460 \\
Geri Dönüşüm Kazanc1 & 0 & 0 & -245431 & -1791221 & -1791221 \\
Net Enerji & 43893 & -31334 & -179233 & -1464026 & -1403474 \\
\hline
\end{tabular}

\subsection{Küresel Isınma Potansiyeli}

Küresel ısınma potansiyelini etkileyen en büyük etkenler metan ve karbondioksit gazlarıdır. Her bir senaryo için küresel 1sınma potansiyeli değerleri hesaplanmış, net küresel ısınma potansiyelleri Şekil 4'te sunulmuştur. Senaryo 1-a, Senaryo 1-b, Senaryo 2 ve Senaryo 3'te küresel 1sınma potansiyeli değeri pozitiftir (sırasıyla 132268, 133290, 110880 ve 28238 ton $\mathrm{CO}_{2}$ eşdeğeri). Buna karşılık Senaryo 4 'te küresel ısınma potansiyeli -49283 ton $\mathrm{CO}_{2}$ eşdeğeri olarak hesaplanmıştır. İşlenen atık başına küresel ısınma potansiyeli değerleri Senaryo 1-a'da 0.8 ton $\mathrm{CO}_{2}$ eşdeğeri/ton atık, Senaryo 1-b'de 0.8 ton $\mathrm{CO}_{2}$ eşdeğeri/ton atık, Senaryo 2'de 0.7 ton $\mathrm{CO}_{2}$ eşdeğeri/ton atık, Senaryo 3'de 0.2 ton $\mathrm{CO}_{2}$ eşdeğeri/ton atık ve Senaryo 4'de ise -0.3 ton $\mathrm{CO}_{2}$ eşdeğeri/ton atıktır. Küresel ısınma potansiyeli sadece Senaryo 4'te negatiftir. Bu durum sadece Senaryo 4'de kompostlama işleminin bulunmasından kaynaklanmaktadır. Düzenli depolama yerine kompostlamanın seçilmesi üretilen metan ve karbondioksit gazı miktarlarını azaltmaktadır.

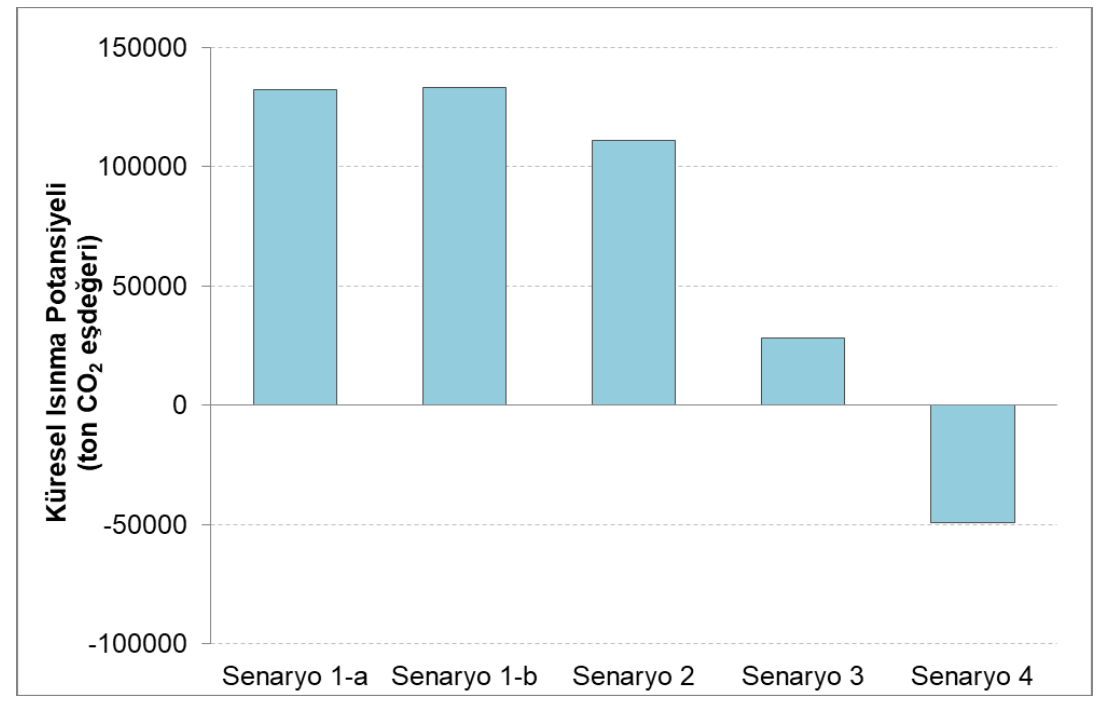

Şekil 4: Katı atık yönetim senaryolarının küresel ısınma potansiyeli açısından karşılaştırılması

Tablo 6'da farklı katı atık yönetim işlemlerinin küresel ısınma potansiyeli gösterilmektedir. Kompostlama işleminin atık yönetimine dâhil edilmesi küresel ısınmaya katkı sağlayan metan ve karbondioksit gazlarının salınımı önemli ölçüde engellemiştir (Tablo 5). Ayrıca geri dönüşüm oranın arttığı Senaryo 2, Senaryo 3 ve Senaryo 4 'te küresel 1sınma etkisini azaltmada etkili olmuştur. 
Tablo 6: Katı atık yönetim senaryolarında farklı işlemlerin küresel ısınma potansiyeline etkisi (kg $\mathrm{CO}_{2}$ eşdeğeri)

\begin{tabular}{lccccc}
\hline Atık Yönetim İşlemi & Senaryo-1a & Senaryo 1b & Senaryo 2 & Senaryo 3 & Senaryo 4 \\
\hline Taşıma ve Transfer & 9151 & 9151 & 9167 & 9241 & 9257 \\
Ayrıştırma & 0 & 0 & 168 & 950 & 950 \\
Geri Dönüşüm & 0 & 0 & 7037 & 26964 & 26964 \\
Düzenli Depolama & 123116 & 124138 & 114361 & 104915 & 26022 \\
Kompostlama & 0 & 0 & 0 & 0 & 1356 \\
Geri Dönüşüm Kazancı & 0 & 0 & -19854 & -113831 & -113831 \\
Net Küresel Isınma Potansiyeli & 132268 & 133290 & 110880 & 28238 & -49283 \\
\hline
\end{tabular}

\subsection{Asidifikasyon Potansiyeli}

Asidifikasyona neden olan emisyonlar $\mathrm{SO}_{x}, \mathrm{NO}_{\mathrm{x}}, \mathrm{NH}_{3}$ ve $\mathrm{HCl}$ 'den kaynaklanmaktadır. Bir kirleticilerin asitlendirme potansiyeli, $\mathrm{H}^{+}$iyonları oluşturma kapasitesiyle ölçülebilir. Asitleşme potansiyeli, $\mathrm{SO}_{2}$ 'ye göre kg başına üretilen $\mathrm{H}^{+}$ iyonlarının sayısı olarak tanımlanır (Bauman ve Tillman 2004). Çalışmada her bir senaryo için oluşturulan asidifikasyon potansiyeli hesaplanmış, yaşam döngüsü net asidifikasyon potansiyeli Şekil 5'te verilmiştir. Senaryo 1-a ve Senaryo 1b'de net asidifikasyon potansiyeli değerleri pozitif ve sırasıyla 24 ve $19 \mathrm{~kg} \mathrm{SO}$ eşdeğeri miktarındadır. Senaryo 2 , Senaryo 3 ve Senaryo 4'de ise asidifikasyon potansiyeli değerleri negatiftir (sırasiyla $-78,-1029$ ve $-1024 \mathrm{~kg} \mathrm{SO}$ eşdeğeri). Negatif değerler asidifikasyon açısından azaltma yönünde etki ortaya çıktığını göstermektedir. Asidifikasyon potansiyeli etkisi toplam atık başına Senaryo 1-a'da $145 \mathrm{mg} \mathrm{SO}$ eşdeğeri /ton atık, Senaryo 1-b'de $115 \mathrm{mg} \mathrm{SO}_{2}$ eşdeğeri /ton atık, Senaryo 2'de $-472 \mathrm{mg} \mathrm{SO}$ eşdeğeri /ton atık, Senaryo 3'de -6236 mg SO 2 eşdeğeri /ton atık ve Senaryo 4'de ise $-6206 \mathrm{mg} \mathrm{SO} 2$ eşdeğeri/ton atık olarak hesaplanmıştır. Geri dönüşüm işlemi asidifikasyon potansiyelini azaltan en önemli işlemdir.

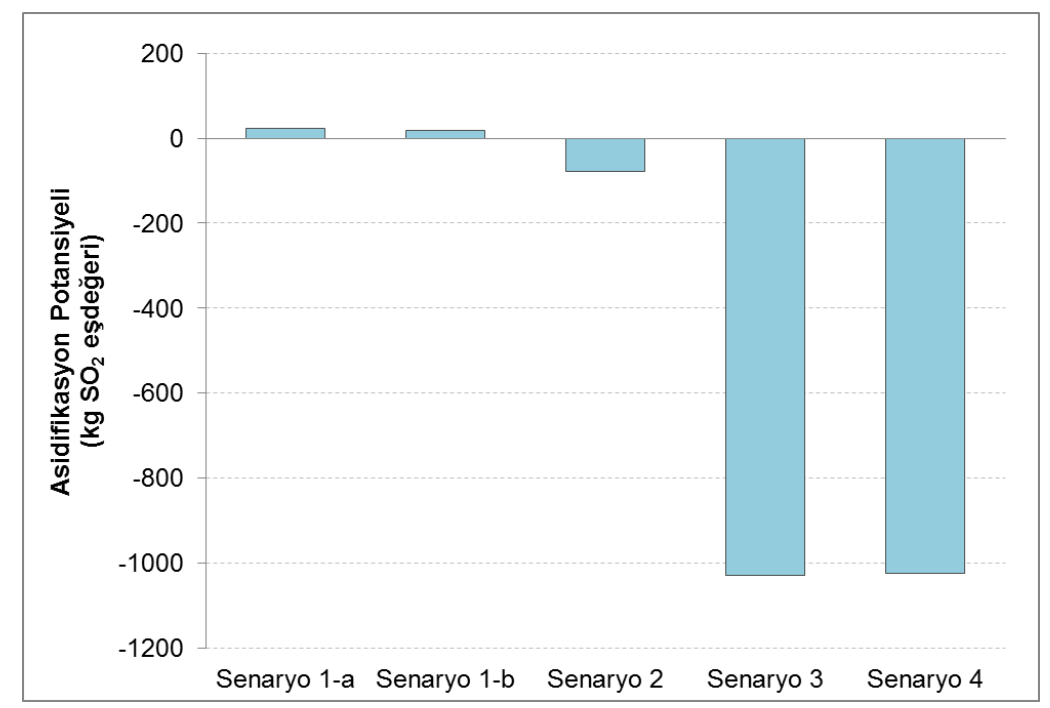

Şekil 5: Katı atık yönetim senaryolarının asidifikasyon potansiyeli açısından karşılaştırılması

Katı atık yönetimi senaryolarında farklı atık yönetim işlemlerinin asidifikasyon potansiyeline etkileri Tablo 7'de gösterilmektedir. Buna göre asidifikasyona en fazla etki eden işlemler taşıma, toplama ve geri dönüşüm adımlarıdır. Buna karşılık geri dönüşümün yapılması asidifikasyon potansiyelini azaltıcı yönde etki etmektedir. 
Tablo 7: Katı atık yönetim senaryolarında farklı işlemlerin asidifikasyon potansiyeline etkisi (kg $\mathrm{SO}_{2}$ eşdeğeri)

\begin{tabular}{lccccc}
\hline Atık Yönetim İşlemi & $\begin{array}{c}\text { Senaryo } \\
1-\mathrm{a}\end{array}$ & $\begin{array}{c}\text { Senaryo } \\
1-\mathrm{b}\end{array}$ & Senaryo 2 & Senaryo 3 & Senaryo 4 \\
\hline Taşıma ve Transfer & 20 & 20 & 20 & 21 & 21 \\
Ayrıştırma & 0 & 0 & 0 & 2 & 2 \\
Geri Dönüşüm & 0 & 0 & 55 & 166 & 166 \\
Düzenli Depolama & 3 & -1 & -1 & -1 & 1 \\
Kompostlama & 0 & 0 & 0 & 0 & 3 \\
Geri Dönüşüm Kazancı & 0 & 0 & -153 & -1216 & -1216 \\
Net Asidifikasyon Potansiyeli & 24 & 19 & -78 & -1029 & -1024 \\
\hline
\end{tabular}

\section{4. Ötrofikasyon}

Ötrofikasyon, karasal ve sucul ekosistemleri etkileyebilen bir olgudur. Ötrofikasyon sonuçları azot eşdeğeri olarak ifade edilmektedir. Ötrofikasyona neden olan hava kirleticileri arasında $\mathrm{NO}_{\mathbf{x}}$ ve $\mathrm{NH}_{3}$ yer almaktadır (Bauman ve Tillman 2004). Çalışmada her senaryo için elde edilen ötrofikasyon potansiyeli ile ilgi bilgiler yaşam döngüsü net ötrofikasyon potansiyeli olarak Şekil 6'da verilmiştir. Senaryo 1-a, Senaryo 1-b ve Senaryo 2'de net ötrofikasyon potansiyeli değerleri pozitif ve sırasıyla $323479 \mathrm{~kg} \mathrm{O}_{2}$ eşdeğeri, $277619 \mathrm{~kg} \mathrm{O}$ eşdeğeri ve $193884 \mathrm{~kg} \mathrm{O}_{2}$ eşdeğeri miktarındadır. Senaryo 3 ve Senaryo 4 için ise ötrofikasyon potansiyelleri $-434703 \mathrm{~kg} \mathrm{O}_{2}$ eşdeğeri ve $-508200 \mathrm{~kg} \mathrm{O}_{2}$ eşdeğeri'dir. Ötrofikasyon değeri toplam atık başına, Senaryo 1-a'da $1.7 \mathrm{~kg} \mathrm{O}_{2}$ eşdeğer/ ton atık, senaryo 1-b'de $2.0 \mathrm{~kg} \mathrm{O}$ eşdeğeri/ton atık, Senaryo 2'de $1.2 \mathrm{~kg} \mathrm{O}_{2}$ eşdeğer/ton atık, Senaryo 3'de $-2.6 \mathrm{~kg} \mathrm{O}$ eşdeğer/ton atık ve Senaryo 4'de ise $-3.1 \mathrm{~kg} \mathrm{\textrm {O } _ { 2 }}$ eşdeğer/ton atık'dır. Senaryo 3 ve Senaryo 4'de bütün geri dönüşebilir atıkların kaynakta ayrıştırılmasından dolayı ötrofikasyon potansiyelinin katkısının düşük olduğu söylenebilir. Senaryo 4'te kompostlama işleminin olması, düzenli depolamaya sistemine göre ötrofikasyon potansiyeline katkısı daha düşük olduğu söylenebilir (Tablo 8).

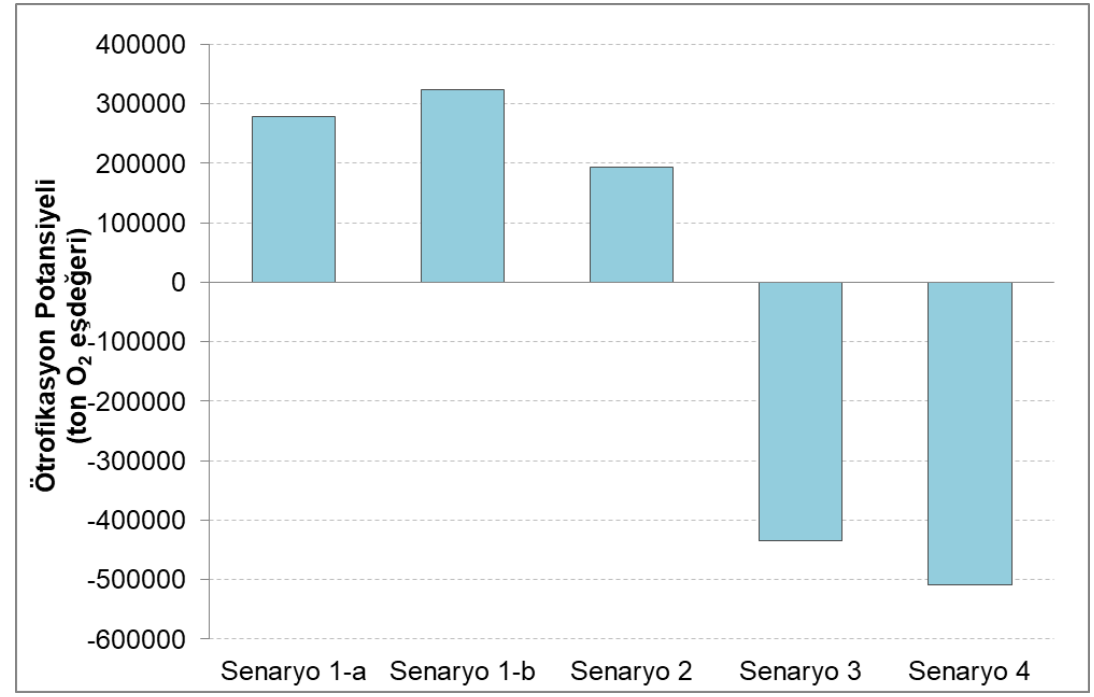

Şekil 6. Katı atık yönetim senaryolarının ötrofikasyon potansiyeli açısından karşılaştırılması

Tablo 7: Katı atık yönetim senaryolarında farklı işlemlerin ötrofikasyon potansiyeline etkisi (ton $\mathrm{O}_{2}$ eşdeğeri)

\begin{tabular}{lccccc}
\hline Atık Yönetim İşlemi & Senaryo 1-a & Senaryo 1-b & Senaryo 2 & Senaryo 3 & Senaryo 4 \\
\hline Taşıma ve Transfer & 128486 & 128486 & 128712 & 129764 & 129980 \\
Ayrıştırma & 0 & 0 & 1333 & 7557 & 7557 \\
Geri Dönüşüm & 0 & 0 & 143296 & 442735 & 442735 \\
Düzenli Depolama & 149132 & 194993 & 187373 & 162451 & 77173 \\
Kompostlama & 0 & 0 & 0 & 0 & 11566 \\
Geri Dönüşüm Kazancı & 0 & 0 & -266829 & -1177210 & -1177210 \\
Net Asidifikasyon Potansiyeli & 277619 & 323476 & 193884 & -434703 & -508200 \\
\hline
\end{tabular}




\section{Tartışma}

$\mathrm{Bu}$ çalışmada Melikgazi ilçesi için evsel katı atık yönetim alternatifleri yaşam döngüsü analizi yaklaşımı ile değerlendirilmiş ve enerji tüketimleri ve çevresel etkileri açısından karşılaştırmaları yapılmıştır. Katı atık yönetiminin etkilerinin değerlendirilmesi ve farklı alternatiflerin karşılaştırılması için bu yaklaşım yararlı bir araç sağlamıştır. Katı atık yönetiminde yaşam döngüsü analizinin kullanımı ile ilgili literatürde pek çok çalışma bulunmaktadır (Khandelwal vd. 2019; Yadav ve Samadder 2018; Laurent vd. 2014). Çoğunlukla Avrupa ve Asya ülkelerinde yapılan bu çalışmaların ülkelerin çevresel duyarlılığındaki artışla ilişkili olduğunu düşünülmektedir (Khandelwal vd. 2019). Bu çalışmalarda kullanılan yöntemler ve veriler ve dikkate alınan yönetim alternatifleri farklı olsa da, yaşam döngüsü analizi belirli bir bölge için katı atık yönetim alternatiflerinin karşılaştırılabilmesi için yararlı bir yöntem sağlamıştır. Özellikle Laurent vd. (2014) tarafından yapılan çalışmada bugüne kadar yapılmış 212 yaşam döngüsü analizi çalışmasının karşılaştırılması hedeflenmiş ancak incelenen her bir katı atık yönetim sistemi için atık bileşimi ve enerji sistemi gibi yerel koşullardaki değişkenliğin sonuçların genellenmesini engellediği ortaya konulmuştur. Bu sonuca istinaden yaşam döngüsü analizinin farklı bölgelerdeki sistemleri karşılaştırmaktan daha çok yerel anlamda farklı alternatiflerin çevresel etkilerinin değerlendirilmesi ve katı atık yönetim sistemin iyileştirilebilmesi için bir araç olduğu vurgulanmıştır. Bu çalışmada da Kayseri ili Melikgazi ilçesi için üretilen farklı yönetim alternatifleri birbirleriyle karşılaştırılmış, aralarında farklılıklar ortaya konulmuş, enerji tüketimi ve çevresel etkiler açısından en önemli olan işlemler ortaya çıkarılmıştır.

Katı atık yönetim sistemlerinde enerji tüketimine neden olan temel aşama atıkların toplanması ve transferidir (Jaunich vd. 2016). Buna karşılık düzenli depolama sahaları önemli miktarlarda metan ve diğer uçucu organik bileşikler, $\mathrm{CO}_{2}$ ve $\mathrm{NO}_{x}$ ve CO üretebilme potansiyeline sahiptir (Mboowa vd. 2017). Atıkların anaerobik bozunması sonucu oluşan metan gazının kullanımı ile enerji geri kazanımı mümkündür. Bu çalışmada enerji tüketimi açısından düzenli depolama esnasında gaz ve enerji kontrolünün mevcut olduğu senaryolar (Senaryo 1b, 2, 3 ve 4) net olarak enerji kazanımın ortaya çıkmasına neden olmuştur. Gaz ve enerji kontrolü söz konusu olduğunda katı atık toplanması ve transferi sırasında kullanılan enerjinin fazlasıyla geri kazanımı mümkün olmaktadır. Bu nedenle düzenli depo sahalarında gaz ve enerji kontrolünün etkinliğinin artırılması enerji tüketimini azaltmak açısından önemlidir.

Düzenli depolama esnasında oluşan metan ve karbondioksit gazları aynı zamanda küresel 1sınma potansiyelini artıran gazlardır. Bu çalışmada düzenli depolanan atık miktarının artması küresel ısınma potansiyelini artırmıştır. Atıkların kaynakta azaltılması, diğer bir ifadeyle geri dönüşebilir atıkların ayrıştırılması söz konusu olduğunda veya düzenli depolama yerine kompostlama işlemi bir seçenek olarak ortaya çıktığında ise küresel 1sınma potansiyeli azalmaktadır. Abduli vd. (2020) düzenli depolama ve kompostlama + düzenli depolama işlemlerinin uygulanması durumunda oluşabilecek çevresel etkileri incelemişlerdir. Çalışma sonuçları kompostlama + düzenli depolamanın daha az zararlı çevresel etkiye yol açtığını göstermiştir. Maalouf ve El-Fadel (2019) küresel ısınma potansiyeli açısından en yüksek etkinin, metan emisyonları nedeniyle tüm atıkların düzenli depolanmasından kaynaklandığını belirtmektedir. Geri dönüşüm ve kompostlama gibi işlemler ise diğer tüm kategorilerle birlikte küresel ısınma potansiyelini azaltma yönünden de katkı sağlamaktadır.

Atık yönetimi esnasında ortaya çıkan $\mathrm{SO}_{x}, \mathrm{NO}_{x}$, ve $\mathrm{HCl}$ gibi maddeler asidifikasyon potansiyelini artırmaktadır (Bauman ve Tillman 2004). Bu gazlar atık toplama ve taşıma, enerji kullanımı ve atık yakma gibi süreçler sonucu oluşabilir. Bu çalışmada atık yakma senaryolar içinde yer alan bir işlem değildir. Bu nedenle en fazla asidifikasyon etkisi toplama ve taşıma işlemlerinden oluşmuştur. Bunun yanında modelde geri dönüşebilir atıklardan madde geri kazanımı süreci de dikkate alınmıştır. Geri dönüşebilir atıkların ayrı toplanması madde geri kazanımı artırarak asidifikasyon etkisini azaltıcı yönde katkı sağlamıştır. Geri dönüşebilir atıkların ayrı toplanmadığı veya ancak kısmen ayrı toplandığı Senaryo 1 ve Senaryo 2'de bu nedenle asidifikasyon potansiyeli pozitif, Senaryo 3 ve Senaryo 4'de ise negatif olarak hesaplanmıştır. Asidifikasyon açısından Senaryo 3 ve Senaryo 4 diğer senaryolara göre daha az etki oluşturan senaryolar olarak ortaya çıkmıştır.

Ötrofikasyon potansiyeli $\mathrm{NO}_{\mathrm{x}}$ ve $\mathrm{NH}_{3}$ gibi azot içeren bileşikler dolayısıyla artmaktadır (Nhubu 2019). Bu çalışmada da en fazla etki toplama ve transfer ve düzenli depolamadan kaynaklanmıştır. Geri dönüşebilir atıkların işlenmesi ve bu atıklarda madde geri kazanımı ötrofikasyon etkisini azaltıcı yönde etki sağlamıştır.

\section{Sonuç ve Öneriler}

Bu çalışmada, IWM modeli kullanılarak Kayseri ili Melikgazi ilçesi için katı atık yönetim alternatifleri yaşam döngüsü analizi kullanılarak karşılaştırılmıştır. Uygulanan katı atık bertaraf yöntemine bağlı olarak Melikgazi ilçesi katı atık yönetim sistemi dört senaryo ile incelenmiştir. Yaşam döngüsü etki kategorileri için senaryoların çevresel profilleri, enerji tüketimi/yenilenemeyen enerji kaynakları tüketme potansiyeli, küresel ısınma potansiyeli, asidifikasyon potansiyeli, ötrofikasyon potansiyeli açısından incelenmiştir. Emisyonlar öncelikle bu etkilere göre kategorize edilmiş ve daha sonra emisyon faktörleri kullanılarak hesaplamalar yapılmıştır.

Çalışmada enerji tüketimi/yenilenemeyen enerji kaynakları tüketme potansiyeli açısından en avantajlı senaryo Senaryo 3 olarak belirlenmiştir. Senaryo 3'te geri dönüşebilir atıklar haricindeki atıklar düzenli depolama ile bertaraf edilmekte, bu işlem sırasında oluşan metan gazi ise enerji üretimi için kullanılmaktadır. Küresel ısınma potansiyeli en düşük olan senaryo Senaryo 4'tür. 
Senaryo 4'te geri dönüşebilir atıklar haricindeki atıkların kısmen düzenli depolama ve kısmen kompostlama işlemleri ile bertaraf edilmektedir. Kompostlama süreci küresel ısınmaya neden olan metan gazının oluşmasını engellediği için senaryonun küresel ısınma potansiyelini azaltmıştır. Asidifikasyon potansiyeli en düşük senaryo Senaryo 3 ve ötrofikasyon potansiyeli en düşük senaryo ise Senaryo 4 olarak belirlenmiştir. Sonuç olarak Melikgazi ilçesi için Senaryo 3 ve Senaryo 4'ün hem enerji tüketimi hem de çevresel etkiler açısından diğer senaryolara göre daha avantajlı oldukları belirlenmiştir.

Yaşam döngüsü analizi, atık yönetim stratejilerinin geliştirilmesinde önemli bir rol oynayabilecek olan entegre katı atık yönetim sisteminin planlanması ve optimize edilmesine yararlı bir araç sağlayabilir. Bu çalışmada atık yönetimi alternatifleri sadece çevresel açıdan modellenmiştir. Bu nedenle, elde edilen sonuçlar gelecekte katı atık yönetiminin ekonomik ve sosyal etkilerini dikkate alan diğer karar verme araçları ile desteklenebilir.

\section{Teşekkür}

Çalışmada kullanılan verileri sağlayan Melikgazi Belediyesi ve Çevre Mühendisi Ramazan AYDIN'a teşekkür ederiz.

\section{Kaynaklar}

Abduli M.A., Naghib A., Yonesi M., Akbari A., (2011), Life cycle assessment (LCA) of solid waste management strategies in Tehran: landfill and composting plus landfill, Environmental Monitoring and Assessment, 178, 487-498.

Balahorli V., Kemirtlek A., Aydoğan Y., (2015), Bursa Entegre Katı Atık Yönetim Planı, İSTAÇ İstanbul Çevre Yönetimi Sanayi ve Tic. A.Ș., İstanbul.

Banar M., Cokaygil Z., Ozkan A., (2009), Life cycle assessment of solid waste management options for Eskisehir, Turkey, Waste Management, 29(1), 54-62.

Bauman H., Tillman A., (2004), The Hitch Hiker's Guide to LCA: An orientation in life cycle assessment methodology and application, Studentlitteratur AB, Sweden, 543ss.

Çetinkaya A.Y., Bilgili L., Kuzu S.L. (2018), Life cycle assessment and greenhouse gas emission evaluation from Aksaray solid waste disposal facility, Air Quality, Atmosphere and Health 11, 549-558.

Chen X., (2012), Life cycle assessment (LCA) of five municipal solid waste management systems (MSWMS): A case study of Nanjing, China, Msc Thesis, Eastern Anglia University, Norwich.

Chen D.M-C., Bodirsky B.L., Krueger T., Mishra A., Popp A. (2020), The world's growing municipal solid waste: trends and impacts, Environmental Research Letters, 15(7):074021, doi: 10.6084/m9.figshare.12102510.

Clift R., Doig A., Finnveden G., (2000), The application of life cycle assessment to integrated solid waste management: Part 1Methodology, process safety and environmental protection, 78(4), 279-287.

Çil S., (2013), Yalova kentsel katı atık yönetim alternatiflerinin çevresel yaşam döngüsü analizi ile incelenmesi, Yüksek Lisans Tezi, Gebze, Kocaeli.

Çokaygil Z., (2005), Atık yönetimi planlamasında yaşam döngüsü analizi. Anadolu Üniversitesi, Yüksek Lisans Tezi, Eskişehir, 2005.

Erses Yay A.S., (2017), Yaşam döngüsü analizinin ambalaj atıklarının yönetiminde kullanılması, Sakarya Üniversitesi Fen Bilimleri Enstitüsü Dergisi, 21(5), 1008-1017.

Ekvall T., Finnveden G., (2000), The application of life cycle assessment to integrated solid waste management: Part 2-Perspectives on energy and material recovery from paper, Process Safety and Environmental Protection, 78 (4), 288-294.

Finnveden G., Johansson J., Lind P., Moberg A., (2005), Life cycle assessment of energy from solid waste -Part 1: General methodology and results, Journal of Cleaner Production, 13(3), 213-229.

Guinee J.B., Heijungs R., Huppes G., Zamagni A., Masoni P., Buonamici R., Ekvall T., Rydberg T., (2011), Life cycle assessment: past, present, and future, Environmental Science Technology, 45 (1), 90-96.

Güereca L.P., Gassó S., Baldasano J.M., Jiménez-Guerrero, P., (2006), Life cycle assessment of two biowaste management systems for Barcelona, Spain, Resources, Conservation and Recycling, 49(1), 32-48.

Hong J., Li X., Zhaojie C., (2010), Life cycle assessment of four municipal solid waste management scenarios in China, Waste Management, 30(11), 2362-2369.

Jaunich M.K., Levis J.W., Barlaz M.A., (2016), Lifecycle process model for municipal solid waste collection, Journal of Environmental Engineering, 142(8):04016037, doi: 10.1061/(ASCE)EE.1943-7870.0001065.

Kaplan P.Ö., Ranjithan S.R., Barlaz M.A., (2009), Use of life-cycle analysis to support solid waste management planning for Delaware, Environmental Science Technology, 43(5), 1264-1270.

Khandelwal H., Dhar H., Thalla A.K., Kumar S. (2019), Application of life cycle assessment in municipal solid waste management: A worldwide critical review, Journal of Cleaner Production, 209, 630-654.

Konstadinos A., (2011), Life cycle assessment in municipal solid waste management, Integrated Waste Management - Volume I'in İçinde (Kumar S., Ed.), IntechOpen, doi: 10.5772/20421.

Laurent A. Bakas I., Clavreul J., Bernstad A., Niero M., Gentil E., Hauschild M.Z., ChristensenT.H., (2014), Review of LCA studies of solid waste management systems - Part I: Lessons learned and perspectives, Waste Management, 34(3), 573-588.

Maalouf A., El-Fadel M., (2019), Life cycle assessment for solid waste management in Lebanon: Economic implications of carbon credit, Waste Management and Research, 37, 14-26.

Mendes M.R., Aramaki T., Hanaki K. (2004), Comparison of the environmental impact of incineration and landfilling in Sao Paulocity as determined by LCA, Conservation and Recycling, 41(1), 47-63.

Mboowa D., Quereshi S., Bhattacharjee C., Tonny K., Dutta S., (2017), Qualitative determination of energy potential and methane generation from municipal solid waste (MSW) in Dhanbad (India), Energy, 123, 386-391. 
Naghibzadeh S.S., Krorasani N., Youseft J., Mousavi B.S., Badehian Z., (2015), Life cycle assessment of municipal waste management system (casestudy: Karaj, Iran), Journal of Applied Sciences and Environmental Management, 18(4), 1119-8362.

Nhubu T., Muzenda E., Mbohwa C., (2019), Eutrophication impact potential of solid waste management options in Harare, 5th International Conference Wastes: Solutions, Treatments and Opportunities, 4-6 September, Costa da Caparica, Lisbon, Portugal.

Othman S.N., Noor Z.Z., Abba A.H., Rafiu O.Y., Mohd A.A.H., (2013), Review on life cycle assessment of integrated solid waste management in some Asian countries, Journal of Cleaner Production, 41, 251-262.

Özeler D., (2001), Life cycle assessment of municipal solid waste treatment methods: Ankara case study, Yüksek Lisans Tezi, Orta Doğu Teknik Üniversitesi, Ankara.

Özeler D. Yetiş Ü., Demirer, G.N. (2006), Life cycle assesment of municipal solid waste management methods: Ankara case study, Environment International, 32(3), 405-411.

Özer B., Yay A.E., (2021), Comparative life cycle analysis of municipal waste management systems: Kirklareli/Turkey case study, Environmental Science and Pollution Research, https://doi.org/10.1007/s11356-020-12247-0.

Özkan A., (2008), Kentsel katı atık yönetimi sistemlerinin oluşturulmasında farklı karar verme tekniklerinin kullanımı, Doktora Tezi, Anadolu Üniversitesi, Eskişehir.

Rives J., Rieradevall J., Gabarrell X., (2010), LCA comparison of container systems in municipal solid waste management, Waste Management, 30(6), 949-957.

SETAC, (1991), A technical framework for life cycle assessment, Society of Environmental Toxicology and Chemistry, Workshop Report: August 18-23, 1990, Smugglers Notch, Vermont, USA.

TEİAŞ, (2017) Türkiye elektrik üretim kaynakları, https://www.teias.gov.tr/tr/turkiye-elektrik-uretim-iletim-istatistikleri, [Erişim 5 Nisan 2018].

URL-1, (2015), Atık Yönetimi Yönetmeliği, Resmi Gazete Tarih: 2 Nisan 2015, Say1: 29314, https://www.resmigazete.gov.tr/ eskiler/2015/04/20150402-2.htm, [Erişim 5 Nisan 2018].

Weitz K.A., Thorneloe S.A., Nishtala, S.R., Yarkosky, S., Zannes, M., (2002), The impact of municipal solid waste management on greenhouse gas emissions in the United States, Journal of theAir \& Waste Management Association, 52(9), 1000-1011.

White P., Franke M., Hindle P., (1995), Integrated Solid Waste Management: A Life Cycle Inventory, Blackie Academic and Professional, 1995.

Yadav P., Samadder S.R., (2018), A critical review of the life cycle assessment studies on solid waste management in Asian countries, Journal of Cleaner Production, 185, 492-515. 